\title{
Effect of insulating existing houses on health inequality: cluster randomised study in the community
}

\begin{abstract}
Philippa Howden-Chapman, professor and director, ${ }^{1}$ Anna Matheson, PhD student, Julian Crane, professor and codirector, ${ }^{2}$ Helen Viggers, data analyst, ${ }^{1}$ Malcolm Cunningham, principal analyst, ${ }^{4}$ Tony Blakely, professor, ${ }^{3}$ Chris Cunningham, professor, ${ }^{5}$ Alistair Woodward, professor, ${ }^{6}$ Kay SavilleSmith, director, ${ }^{7}$ Des O'Dea, lecturer, ${ }^{1}$ Martin Kennedy, adviser, ${ }^{8}$ Michael Baker, senior lecturer and codirector, ${ }^{1}$ Nick Waipara, scientist, ${ }^{9}$ Ralph Chapman, associate professor, ${ }^{10}$ Gabrielle Davie, biostatistician ${ }^{1}$
\end{abstract}

${ }^{1}$ He Kainga Oranga, Housing and Health Research Programme, University of Otago, Wellington, PO Box 7343, Wellington South, New Zealand

${ }^{2}$ Department of Medicine, University of Otago

${ }^{3}$ Department of Public Health, University of Otago

${ }^{4}$ Building Research Association of New Zealand, Porirua City, New

Zealand

${ }^{5}$ Research Centre for Maori Health and Development, Massey University, Wellington

${ }^{6}$ School of Population Health, University of Auckland, Auckland

${ }^{7}$ Centre for Research Evaluation and Social Assessment (CRESA), Wellington

${ }^{8}$ Ministry for the Environment, Wellington

${ }^{9}$ Landcare Research, Auckland

${ }^{10}$ School of Geography,

Environment and Earth Sciences, Victoria University of Wellington, Wellington

Correspondence to:

P Howden-Chapman

howdenc@wnmeds.ac.nz

doi: 10.1136/bmj.39070.573032.80

\section{ABSTRACT}

Objective To determine whether insulating existing houses increases indoor temperatures and improves occupants' health and wellbeing.

Design Community based, cluster, single blinded randomised study.

Setting Seven low income communities in New Zealand.

Participants 1350 households containing 4407

participants.

Intervention Installation of a standard retrofit insulation package.

Main outcome measures Indoor temperature and relative humidity, energy consumption, self reported health, wheezing, days off school and work, visits to general practitioners, and admissions to hospital.

Results Insulation was associated with a small increase in bedroom temperatures during the winter $\left(0.5^{\circ} \mathrm{C}\right)$ and decreased relative humidity $(-2.3 \%)$, despite energy consumption in insulated houses being $81 \%$ of that in uninsulated houses. Bedroom temperatures were below $10^{\circ} \mathrm{C}$ for 1.7 fewer hours each day in insulated homes than in uninsulated ones. These changes were associated with reduced odds in the insulated homes of fair or poor self rated health (adjusted odds ratio 0.50, 95\% confidence interval 0.38 to 0.68 ), self reports of wheezing in the past three months $(0.57,0.47$ to 0.70$)$, self reports of children taking a day off school $(0.49,0.31$ to 0.80$)$, and self reports of adults taking a day off work $(0.62,0.46$ to 0.83$)$. Visits to general practitioners were less often reported by occupants of insulated homes $(0.73,0.62$ to 0.87). Hospital admissions for respiratory conditions were also reduced $(0.53,0.22$ to 1.29$)$, but this reduction was not statistically significant $(\mathrm{P}=0.16)$.

Conclusion Insulating existing houses led to a significantly warmer, drier indoor environment and resulted in improved self rated health, self reported wheezing, days off school and work, and visits to general practitioners as well as a trend for fewer hospital admissions for respiratory conditions. Trial registration Clinical Trials NCT00437541.

\section{INTRODUCTION}

The quality of housing affects the health of the population. Improvements to housing could potentially prevent ill health, especially in sections of the population exposed to substandard housing. ${ }^{12}$ Several reviews of social interventions, and housing interventions in particular, have highlighted a dearth of studies in this area and the urgent need for studies from which causal inferences can be drawn. ${ }^{3-6}$ People in developed countries spend more than $90 \%$ of their time indoors, most of it in their own homes, but we know little about the specific health effects of the indoor environment. ${ }^{78}$ The housing, insulation and health study is a cluster randomised trial of insulating existing houses in low income communities. The study was designed as a practical intervention to improve the indoor environment at the community level.

The British Wanless report stated that "every opportunity to generate evidence from current policy and practice" should be taken to provide more robust evidence of practical interventions that might help governments formulate effective policies. ${ }^{9}$ Because evidence that improving housing can significantly reduce morbidity is limited, we focused on houses as the main unit of analysis to provide evidence for use in formulating public policy. Fitting insulation into houses, rather than intervening at the level of the individual - for example, by providing people with more clothes - could be a more cost effective and practical way to improve health. ${ }^{10}$

Badly constructed and older houses are difficult and expensive to heat. Inadequate warmth in the home can have health consequences for the occupants, particularly during winter. ${ }^{112}$ The efficiency of domestic energy is linked with health because money spent on energy cannot be spent on other necessities such as food. ${ }^{1314}$ Colder houses place more physiological stress on older people, babies, and sick people, who have less robust thermoregulatory systems and are also likely to spend more time inside. ${ }^{15}$ Houses that are cold are also likely to be damp, and this can lead to the growth of moulds, which can cause respiratory 
symptoms. ${ }^{1617}$ The link between inadequate heating; damp, cold, and mouldy houses; and poor health has been highlighted in several international reports. ${ }^{17-21}$ Surprisingly, excess mortality in winter is more pronounced in temperate rather than colder climates, suggesting that houses in these regions do not adequately protect occupants from the weather. ${ }^{1015}$

\section{METHODS}

The study methods, including power considerations and randomisation, have been published previously, but a brief summary is given below. ${ }^{22}$ Figure 1 outlines the flow of households through the study. ${ }^{23}$

\section{Setting}

New Zealand has a temperate climate, with mean winter daytime temperatures ranging from $10^{\circ} \mathrm{C}$ in the south to $16^{\circ} \mathrm{C}$ in the north. ${ }^{24}$ Two thirds of the housing stock comprises three bedroom and four bedroom stand alone wooden houses on wood or concrete piles (Statistics New Zealand, www.stats.govt.nz/ default.htm). Houses usually last about 90 years and about a third have no insulation. Most people only heat the living room and occasionally a bedroom. ${ }^{25}$

Our study was established in seven geographical areas, three urban and four rural, in partnership with local We obtained ethical approval from all sites.

\section{Recruitment}

We selected participants for the study through local organisations, which also obtained informed consent. Each community selected 200 households. ${ }^{26}$ The selected households were in uninsulated dwellings; at least one household member had reported respiratory symptoms in the past year - such as recurrent wheezing — or had a history of asthma, pneumonia, or chest infections; and members were planning to remain in the dwelling for the next two winters.

Sample size calculations were based on the number of people whose health status could be expected to improve

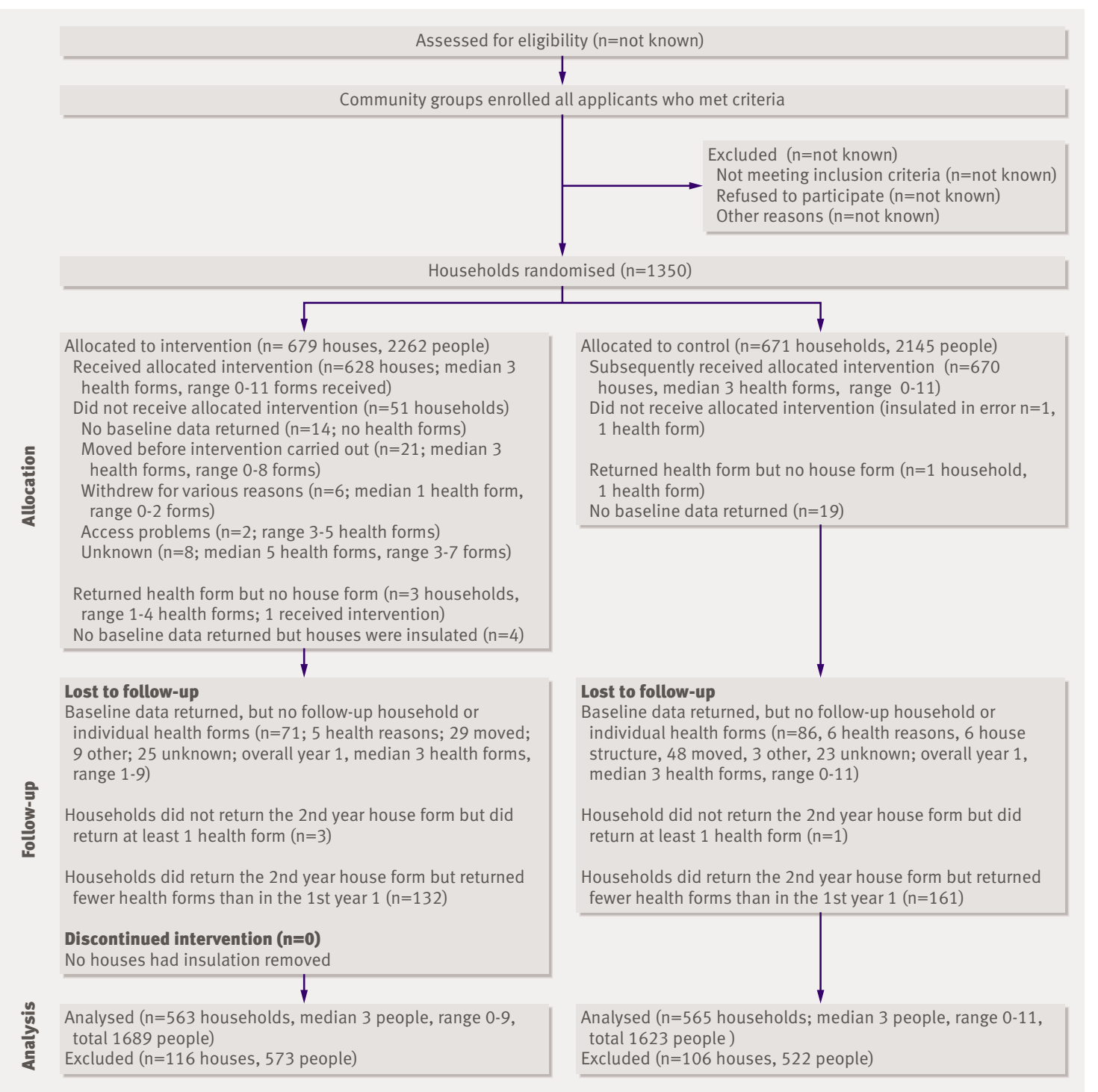


Table 1 Baseline data in a trial of insulating houses. Values are number/total number (percentage) of people

\begin{tabular}{lcc}
\cline { 2 - 3 } & \multicolumn{2}{c}{ Group } \\
\cline { 2 - 3 } Characteristic & $\begin{array}{c}\text { Intervention } \\
(\mathbf{n}=2262)\end{array}$ & $\begin{array}{c}\text { Control } \\
(\mathrm{n}=2145)\end{array}$ \\
Female & $1185 / 2262(52)$ & $1112 / 2145(52)$ \\
\hline Ethnic origin* & \\
\hline $\begin{array}{l}\text { New Zealand European } \\
\text { and "other" }\end{array}$ & $877 / 2196(40)$ & $826 / 2109(39)$ \\
\hline Maori & $1106 / 2196(50)$ & $1001 / 2109(48)$ \\
\hline Pacific & $501 / 2196(23)$ & $578 / 2109(27)$ \\
\hline Age (years) & $294 / 2262(13)$ & $248 / 2145(12)$ \\
\hline $0-4$ & $565 / 2262(25)$ & $522 / 2145(24)$ \\
\hline $5-14$ & $230 / 2262(10)$ & $236 / 2145(11)$ \\
\hline $15-24$ & $594 / 2262(26)$ & $590 / 2145(28)$ \\
\hline $25-44$ & $391 / 2262(17)$ & $362 / 2145(17)$ \\
\hline $45-64$ & $188 / 2262(8)$ & $187 / 2145(9)$ \\
\hline$\geq 65$ & $445 / 2243(20)$ & $437 / 2131(21)$ \\
\hline Health rated fair or poor & &
\end{tabular}

Denominators vary owing to missing data.

*Ethnic origin was self defined; multiple ethnic affiliations possible.

from "fair" or "poor" on the generalised health question in the SF-36 (short form 36) questionnaire. ${ }^{2227}$

\section{Participants}

The study comprised 1350 houses. The tenure patterns showed some divergence from the 2001 New Zealand Census: $24 \%$ of houses in the study were rented compared with $32.2 \%$ nationally; $11 \%$ were rented from public landlords, compared with about $6 \%$ nationally. About a third of the houses were in the lowest tenth of socioeconomic areas, and two thirds were in the bottom three tenths, so that participants were likely to be vulnerable to ill health. Twenty per cent rated their health as poor or very poor, compared with $13 \%$ of the general population.

The initial, regionally stratified randomisation was carried out by an independent biostatistician. Table 1 shows no evidence for systematic bias.

\section{Intervention}

Households randomly allocated to the intervention group had their houses insulated after the baseline measures were taken in the study's first winter (June to August 2001). The intervention consisted of installing ceiling insulation, draught stopping around windows and doors, and fitting sisalated paper beneath floor joists and a polythene moisture barrier on the ground beneath the house. The insulation, which was free to householders, was to government specifications (resistance value 2.4) and was installed by trained community teams. (Households in the control group were insulated for equity at the end of the study after all data had been collected.)

\section{Outcome measures}

The study used interviewer administered questionnaires; participants' self reported experience; as well as independent measures of use of health services, house temperature, and other environmental characteristics of the houses (table 2). Most questions had been used in previous housing surveys). ${ }^{28}$

In spring 2001 and 2002, all household members 11 years and over completed a self administered questionnaire about their health, contact with the health system, smoking, and time lost from work or normal activities because of ill health. This included a subset of three SF-36 full scales (role physical, role emotional, and social functioning), the transitional health question, and a single question from two scales-general health and vitality. Care givers or parents completed a similar but age appropriate questionnaire for infants and children under 11 years.

We checked use of primary care by contacting the specified general practitioners. The number, duration, and main ICD-10 (international classification of diseases, 10th revision) codes for hospital admissions were collected through a data matching process using the unique national patient identifier number.

Participants reported daily whether they felt warm, OK, or cold, before their evening meal. The head of the household also completed an interviewer administered questionnaire in the home about household demographics, dwelling characteristics, and space heatingincluding estimates of the use of solid fuel. The interviewers were told to make no leading comments about the households' insulation status. Regional electricity and gas companies supplied data on the energy consumption of each household during the study period.

\begin{tabular}{|c|c|}
\hline Outcome & Measure \\
\hline \multicolumn{2}{|l|}{ Household } \\
\hline \multirow[t]{3}{*}{ Warmth and dampness } & Self reported dampness and warmth \\
\hline & $\begin{array}{l}\text { Measured temperature and relative } \\
\text { humidity }\end{array}$ \\
\hline & Comfort charts \\
\hline \multirow[t]{2}{*}{ Energy use } & Self reported fuel usage \\
\hline & Measured data from energy companies \\
\hline \multirow[t]{2}{*}{ Subjective fungal activity } & Musty smell \\
\hline & Observed mould \\
\hline \multirow[t]{4}{*}{ Measured fungal activity* } & Mould speciation \\
\hline & Mould mass \\
\hline & Endotoxins \\
\hline & $\beta$ Glucans \\
\hline Allergens* & Dust mite allergens \\
\hline $\begin{array}{l}\text { Environmental tobacco } \\
\text { smoke* }^{\star}\end{array}$ & Smoking behaviour \\
\hline \multicolumn{2}{|l|}{ Individual } \\
\hline \multirow{4}{*}{$\begin{array}{l}\text { Self reported health and use of } \\
\text { healthcare facilities }\end{array}$} & SF-36 scales \\
\hline & Respiratory symptoms \\
\hline & Days off work and school \\
\hline & Questions on use of healthcare facilities \\
\hline Health risk behaviour* & Smoking \\
\hline $\begin{array}{l}\text { Measured use of healthcare } \\
\text { facilities }\end{array}$ & Number of visits to general practitioner \\
\hline
\end{tabular}




\begin{tabular}{|c|c|c|}
\hline \multirow[b]{2}{*}{ Household factors at baseline } & \multicolumn{2}{|c|}{ Group } \\
\hline & Intervention $(n=679)$ & Control $(n=671)$ \\
\hline \multicolumn{3}{|l|}{ Self reports } \\
\hline Dwelling reported in poor or very poor condition & $116 / 644(18)$ & $118 / 653(18)$ \\
\hline Condensation & $566 / 633(89)$ & $577 / 640(90)$ \\
\hline Dampness not due to condensation & $413 / 613(67)$ & $437 / 641(68)$ \\
\hline Mould & $481 / 643(75)$ & 490/651 (75) \\
\hline Smoking reported inside the house during winter & 264/641 (41) & 254/656 (39) \\
\hline Dwelling cold always or most of the time & $452 / 647(70)$ & $473 / 651(73)$ \\
\hline \multicolumn{3}{|l|}{ Building inspector reports } \\
\hline Maintenance poor or very poor & $37 / 70(53)$ & $36 / 69(52)$ \\
\hline Any mould & $59 / 70(84)$ & $54 / 69(78)$ \\
\hline Large patches of mould & $18 / 70(26)$ & $16 / 69(23)$ \\
\hline
\end{tabular}

In 140 randomly selected houses, we recorded temperature and relative humidity in the main bedroom, every 15 minutes, during both winters. At two randomly selected houses in each of the seven communities, temperature and humidity were also continuously recorded outside.

\section{Statistical methods}

We analysed the data in several ways on an intention to treat basis. As randomisation led to no discernible systematic biases, we compared the follow-up scores of the intervention and control groups and subtracted follow-up scores from baseline scores to derive change scores. The analysis of covariance (ANCOVA), the preferred approach, is presented unless otherwise indicated. ANCOVA adjusts each participant's follow-up score for baseline score, but has the advantage of being unaffected by differences at baseline. ${ }^{29}$ Analyses also controlled for the clustering of individuals within households and households within regions. ${ }^{30}$ We routinely added sex, ethnic origin, and age group to the adjusted model; this decision was made a priori. We used SAS software (version 9.1, SAS Institute) and the Glimmix procedure for binary or normal data or STATA (version 8.2, StataCorp) and a zero inflated negative binomial model for count data.

Where odds ratios are presented, a value less than 1 represents a positive effect of insulation whereas a value more than 1 indicates a negative effect of insulation. In general, we adjusted variables for age, sex, region, and baseline values. The unadjusted odds ratios presented take account of clustering. Indicative samples of the most important outcome measures are presented here; others will be presented elsewhere.

\section{RESULTS}

We recruited 1350 households; baseline household information was obtained from 1309 of these households and 4407 people. At follow-up, 1128 households and 3312 people remained-an $86 \%$ retention rate for households and a $75 \%$ rate for people. The proportion of indigenous Maori people (49\%) and migrant Pacific people (22\%) was higher in the sample than in the national population $(15 \%$ and $6 \%$, respectively).

\section{Household factors}

The houses in the study were typical of low socioeconomic status dwellings. Self reporting showed that $18 \%$ were in poor or very poor condition, $89 \%$ had condensation, and 75\% had mould. Building inspectors reported even worse conditions, with 53\% of the houses in the 140 random subsample being in poor or very poor condition and $81 \%$ with some mould (table 3).

\section{Weather}

Winter in both years was broadly comparable. Mean daytime temperatures were $10.5^{\circ} \mathrm{C}$ and $11.3^{\circ} \mathrm{C}$ in 2001 and 2002 .

\section{Indoor environment}

The odds of feeling cold always or most of the time decreased significantly in the insulated houses compared with uninsulated houses (adjusted odds ratio $0.06,95 \%$ confidence interval 0.04 to $0.09 ; \mathrm{P}<0.0001$; table 4). The odds of reporting ineffective heating after intervention was significantly lower for insulated houses $(0.38,0.25$ to $0.57 ; \mathrm{P}<0.0001$; table 4$)$.

Mean bedroom temperature increased in the insulated houses from $13.6^{\circ} \mathrm{C}$ to $14.2^{\circ} \mathrm{C}$ and in the uninsulated ones from $13.2^{\circ} \mathrm{C}$ to $13.4^{\circ} \mathrm{C}$. Mean relative humidity decreased in the insulated houses from $68.6 \%$ to $64.8 \%$ compared with $68.3 \%$ to $66.9 \%$ in the uninsulated houses (table 5). Figure 2 shows the smoothed empirical temperature frequency (area under the curve) over a 24 hour period. Bedroom temperatures were below $10^{\circ} \mathrm{C}$ for an hour less in insulated houses and 45 minutes longer in the uninsulated houses

\section{Reported damp and mould}

At baseline, two thirds of households reported damp and three quarters reported mould, but after insulation the odds of insulated households reporting dampness $(0.18,0.13$ to $0.24 ; \mathrm{P}<0.0001)$ or mould $(0.24$, 0.18 to $0.32 ; \mathrm{P}<0.0001)$ decreased significantly (table 4).

\section{Energy usage}

Electricity and gas company data, and calculations from self reported wood and coal usage using standard calorific values, showed that a geometric mean $\mathrm{kWh}$ equivalent of 3899 was used in the intervention group compared with $4941 \mathrm{kWh}$ in the control arm. After adjusting for baseline usage, this equated to the insulated households consuming $81 \%$ of that consumed by control households $(81 \%$ effect, $72 \%$ to $91 \% ; \mathrm{P}=0.0006$; table 4$)$. Taking a subsample of households ( $\mathrm{n}=136)$, who used only electricity and mains gas in both years, the estimated value of fuel 
Table $4 \mid$ Household results in a trial of insulating houses. Values are number/total number of households for self reported house condition and median/geometric mean (number of households) for energy use, unless stated otherwise

\begin{tabular}{|c|c|c|c|c|c|c|}
\hline \multirow[b]{2}{*}{ Outcome measure } & \multicolumn{2}{|c|}{ Before intervention } & \multicolumn{2}{|c|}{ After intervention } & \multicolumn{2}{|c|}{ Odds ratio $(95 \% \mathrm{Cl})$} \\
\hline & $\begin{array}{l}\text { Interven- } \\
\text { tion group }\end{array}$ & $\begin{array}{l}\text { Control } \\
\text { group }\end{array}$ & Intervention group & Control group & Unadjusted & Adjusted \\
\hline \multicolumn{7}{|c|}{ Self reported condition of house* } \\
\hline Any mould & $364 / 509$ & $362 / 501$ & $191 / 509$ & $343 / 501$ & 0.28 (0.21 to 0.36$) \mathrm{P}<0.0001$ & $\begin{array}{c}0.24 \text { (0.18 to } 0.32) \\
\text { P<0.0001 }\end{array}$ \\
\hline $\begin{array}{l}\text { House cold most of } \\
\text { the time or always }\end{array}$ & $398 / 550$ & $383 / 547$ & $95 / 550$ & $378 / 547$ & 0.09 (0.07 to 0.12$) \mathrm{P}<0.0001$ & $\begin{array}{c}0.06 \text { (0.04 to } 0.09) \\
P<0.0001\end{array}$ \\
\hline Condensation & $487 / 538$ & $486 / 535$ & $318 / 538$ & $480 / 535$ & 0.17 (0.12 to 0.23$) P<0.0001$ & $\begin{array}{c}0.16(0.11 \text { to } 0.22) \\
P<0.0001\end{array}$ \\
\hline $\begin{array}{l}\text { Non-condensation } \\
\text { dampness }\end{array}$ & $334 / 519$ & $324 / 516$ & $156 / 519$ & $339 / 516$ & 0.23 (0.18 to 0.30$) P<0.001$ & $\begin{array}{c}0.18 \text { (0.13 to } 0.24) \\
P<0.0001\end{array}$ \\
\hline Heating ineffective $†$ & $61 / 304$ & $104 / 375$ & $48 / 304$ & $125 / 375$ & 0.38 (0.26 to 0.55$) P<0.0001$ & $\begin{array}{c}0.38(0.25 \text { to } 0.57) \\
\text { P<0.0001 }\end{array}$ \\
\hline \multicolumn{7}{|l|}{ Energy use (kWhre) } \\
\hline $\begin{array}{l}\text { Measured and self } \\
\text { reported } \ddagger\end{array}$ & $\begin{array}{l}4722 / 5016 \\
(195)\end{array}$ & $\begin{array}{c}4583 / 5120 \\
(193)\end{array}$ & $3678 / 3899$ (195) & $\begin{array}{l}4866 / 4941 \\
(193)\end{array}$ & $0.79(0.64$ to 0.97$) P=0.02$ & $\begin{array}{c}0.81(0.72 \text { to } 0.91) \\
P=0.0006\end{array}$ \\
\hline Measured only§ & $\begin{array}{c}2416 / 2451 \\
(72)\end{array}$ & $\begin{array}{c}2392 / 2317 \\
(64)\end{array}$ & $2298 / 2200(72)$ & $\begin{array}{c}2592 / 2328 \\
(64)\end{array}$ & $0.95(0.77$ to 1.16$) \mathrm{P}=0.06$ & $\begin{array}{c}0.92 \text { (0.83 to 1.02) } \\
P=0.097\end{array}$ \\
\hline $\begin{array}{l}\text { Measured and self } \\
\text { reportedף }\end{array}$ & - & - & $3828 / 3847$ (267) & $\begin{array}{c}4628 / 4262 \\
(295)\end{array}$ & 0.90 (0.77 to 1.05$) \mathrm{P}=0.20$ & 0.91 (0.79 to 1.04$) \mathrm{P}=0.17$ \\
\hline
\end{tabular}

${ }^{\star}$ Question answered for both years and adjusted for baseline status, region, and amount of sunshine.

†Excludes those who reported using no heating in either year.

łEstimated full fuel data for both years, including self reported wood, coal, and liquefied petroleum gas; adjusted for region and fuel use in year 1. §Full fuel data for both years; households use only electricity and mains gas; adjusted for region and fuel use in year 1 .

ॠHouseholds with full fuel data for year 2 only; adjusted for region only.

Table 5 | Temperature and relative humidity in a trial of insulating houses

\begin{tabular}{|c|c|c|c|c|c|c|}
\hline \multirow[b]{2}{*}{ Outcome* } & \multicolumn{2}{|c|}{ Before intervention } & \multicolumn{2}{|c|}{ After intervention } & \multicolumn{2}{|c|}{ Difference $(95 \% \mathrm{Cl})$} \\
\hline & $\begin{array}{l}\text { Interven- } \\
\text { tion group }\end{array}$ & $\begin{array}{l}\text { Control } \\
\text { group }\end{array}$ & $\begin{array}{l}\text { Interven- } \\
\text { tion group }\end{array}$ & $\begin{array}{l}\text { Control } \\
\text { group }\end{array}$ & Unadjusted & Adjusted for baseline score \\
\hline Temperature $\left({ }^{\circ} \mathrm{C}\right)$ & 13.6 & 13.2 & 14.2 & 13.4 & $0.40(0.10$ to 0.70$) \mathrm{P}=0.05$ & $0.50(0.03$ to 0.96$) \mathrm{P}=0.04$ \\
\hline Relative humidity (\%) & 68.6 & 68.3 & 64.8 & 66.9 & $-2.4(-3.70$ to -1.10$) \mathrm{P}=0.05$ & $-2.3(-4.20$ to -0.30$) \mathrm{P}=0.02$ \\
\hline Average hours $/$ day $<10^{\circ} \mathrm{C}$ & 3.25 & 4.02 & 2.26 & 4.47 & $\begin{array}{c}-1.44(-2.12 \text { to }-0.76) \\
P=0.007\end{array}$ & $-1.66(-2.56$ to -0.76$) P=0.001$ \\
\hline $\begin{array}{l}\text { Average hours/day }>75 \% \\
\text { relative humidity }\end{array}$ & 6.81 & 6.78 & 4.57 & 6.69 & $\begin{array}{c}-2.15(-3.23 \text { to }-1.07) \\
\mathrm{P}=0.01\end{array}$ & $-2.13(-3.38$ to -0.88$) \mathrm{P}=0.003$ \\
\hline
\end{tabular}

*Measured for both years on a subsample.

savings was around $£ 25$ (€37; \$49; excluding taxes) a year.

\section{SF-36}

Self reported health improved significantly in the intervention group (table 6). Participants in insulated houses were significantly less likely to report poor or fair health $(0.50,0.38$ to $0.68 ; \mathrm{P}<0.0001)$. On the social functioning scale, participants in insulated houses reported 6.2 percentage point improvement relative to the control group (3.8 to 8.6); this improvement was 10.9 percentage points on the role emotional scale $(\mathrm{P}<0.0001)$ and 11.8 percentage points on the role physical scale $(\mathrm{P}<0.0001)$ (table 7$)$. People in the intervention group had 0.56 times the odds of being in the bottom half of a reduced mental health scale ( 0.41 to $0.77 ; \mathrm{P}=0.0003$ ).

People in insulated houses had about half the odds of respiratory symptoms, such as recent wheezing $(0.57$, 0.47 to $0.70 ; \mathrm{P}<0.0001)$ and self reported winter colds and flu $(0.54,0.43$ to $0.66 ; \mathrm{P}<0.0001)$ as those in the control group. In adults, the incidence of morning phlegm decreased significantly $(0.64,0.52$ to 0.78 ; $\mathrm{P}<0.0001$ ), and in children under 13 years the likelihood that the symptoms of wheezing would disturb

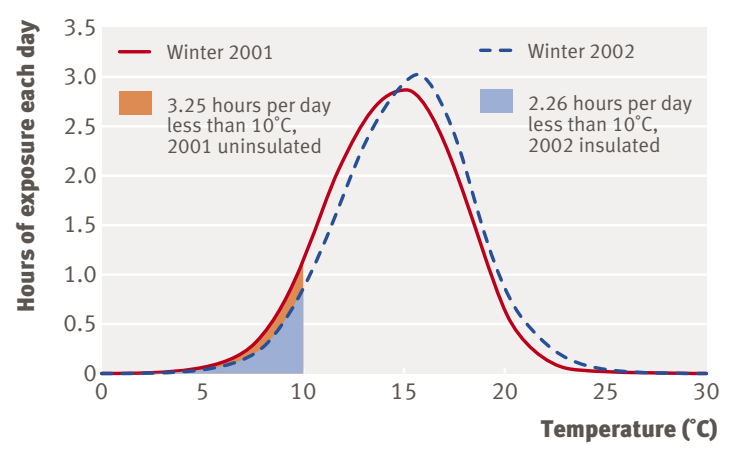

Fig 2 Bedroom temperatures in houses from intervention and control groups. The area under the frequency curves is proportional to the average number of hours each day below $10^{\circ} \mathrm{C}$ 
sleep $(0.57,0.40$ to $0.81 ; \mathrm{P}=0.0019)$ or speech $(0.51$, 0.31 to $0.86 ; \mathrm{P}=0.012$ ) halved (table 6 ).

\section{Days off school and work}

Children in insulated houses were reported to have half the odds of having a day off school compared with the control group $(0.49,0.31$ to $0.80 ; \mathrm{P}=0.004)$, and fewer adults reported having had a day off work $(0.62,0.46$ to $0.83 ; \mathrm{P}=0.0017)$. When we analysed the data on days off work, we added the presence of nonworking adults in the house to the model a priori to account for the situation at home (such as having someone able to care for sick children).

\section{General practitioner visits}

We received records from general practitioners for $82 \%$ of the participants. Self reports showed that visits to general practitioners were significantly lower for insulated houses $(0.73,0.62$ to $0.87 ; \mathrm{P}=0.0002)$, but the difference was not significant according to general practitioner records $(0.95,0.81$ to $1.13 ; \mathrm{P}=0.58)$ (table 8).

\section{Hospital admissions}

We were able to access the National Health Index number (and therefore the hospital records) for $80 \%$ of participants. We found little overall difference in the number of people who were admitted to hospitals for all causes between the intervention group and control group (4.4\% $v 4.7 \%)$. For respiratory conditions such as pulmonary disease and obstructive airways diseases, however, people from insulated houses were less likely to be admitted to hospital $(0.8 \% v 1.3 \%$; 0.53 , 0.22 to $1.29 ; \mathrm{P}=0.16$ ). For conditions other than respiratory diseases, which are less likely to be related to quality of housing, the difference between the study

\begin{tabular}{|c|c|c|c|c|c|c|}
\hline \multirow[b]{2}{*}{ Outcome measure } & \multicolumn{2}{|c|}{ Before intervention } & \multicolumn{2}{|c|}{ After intervention } & \multicolumn{2}{|c|}{ Odds ratio $(95 \% \mathrm{Cl})$} \\
\hline & $\begin{array}{l}\text { Intervention } \\
\text { group }\end{array}$ & $\begin{array}{l}\text { Control } \\
\text { group }\end{array}$ & $\begin{array}{l}\text { Interven- } \\
\text { tion group }\end{array}$ & $\begin{array}{l}\text { Control } \\
\text { group }\end{array}$ & Unadjusted & Adjusted \\
\hline \multicolumn{7}{|c|}{ SF-36 self report scales (adults with data for both years) } \\
\hline Low vitality (bottom 3 of 6 categories) & $445(967)$ & $450(954)$ & $290(967)$ & $412(954)$ & $\begin{array}{c}0.57 \text { (0.47 to } 0.68) \\
\text { P<0.0001 }\end{array}$ & 0.51 (0.41 to 0.64$) P<0.0001^{*}$ \\
\hline $\begin{array}{l}\text { Low happiness score (bottom half of } \\
\text { scale) }\end{array}$ & $158(960)$ & $147(944)$ & $81(960)$ & $127(944)$ & $\begin{array}{l}0.59(0.44 \text { to } 0.80) \\
P=0.0005\end{array}$ & 0.56 (0.41 to 0.77$) \mathrm{P}=0.0003^{*}$ \\
\hline Fair or poor general health & $231(977)$ & $245(964)$ & $145(977)$ & $220(964)$ & $\begin{array}{l}0.59(0.47 \text { to } 0.74) \\
P<0.0001\end{array}$ & $0.50(0.38$ to 0.68$) \mathrm{P}<0.0001^{*}$ \\
\hline \multicolumn{7}{|l|}{ Self reported symptoms } \\
\hline $\begin{array}{l}\text { Colds or flu (participants with data for } \\
\text { both years + babies) }\end{array}$ & - & - & $\begin{array}{c}855 \\
(1481)\end{array}$ & $\begin{array}{c}1002 \\
(1428)\end{array}$ & $\begin{array}{l}0.58 \text { (0.48 to } 0.68) \\
\text { P } 0.001\end{array}$ & 0.54 (0.43 to 0.66$) P<0.0001 \dagger$ \\
\hline $\begin{array}{l}\text { Wheezing in past } 3 \text { months } \\
\text { (participants with data for both years) }\end{array}$ & 591 (1409) & $\begin{array}{c}598 \\
(1366)\end{array}$ & $\begin{array}{c}412 \\
(1409)\end{array}$ & $\begin{array}{c}544 \\
(1366)\end{array}$ & $\begin{array}{c}0.63(0.53 \text { to } 0.73) \\
P<0.0001\end{array}$ & 0.57 (0.47 to 0.70$) P<0.0001^{*}$ \\
\hline $\begin{array}{l}\text { Morning phlegm (adults in matched } \\
\text { set who answered in year } 2 \text { ) }\end{array}$ & - & - & $283(965)$ & $376(961)$ & $\begin{array}{l}0.65(0.53 \text { to } 0.78) \\
P<0.0001\end{array}$ & $0.64(0.52$ to 0.78$) P<0.0001 \dagger$ \\
\hline $\begin{array}{l}\text { Sleep disturbed by wheezing (children } \\
0-12 \text { years, both years) }\end{array}$ & $233(512)$ & $214(471)$ & $142(512)$ & $175(471)$ & $\begin{array}{l}0.65(0.50 \text { to } 0.85) \\
P=0.0017\end{array}$ & $0.57(0.40$ to 0.81$) \mathrm{P}=0.0019 \ddagger$ \\
\hline $\begin{array}{l}\text { Speech disturbed by wheezing } \\
\text { (children 0-12 years, both years) }\end{array}$ & $73(507)$ & $72(468)$ & $35(507)$ & $55(468)$ & $\begin{array}{c}0.56(0.36 \text { to } 0.87) \\
P=0.0099\end{array}$ & $0.514(0.31$ to 0.86$) \mathrm{P}=0.0120 \ddagger$ \\
\hline \multicolumn{7}{|l|}{ Days off work } \\
\hline $\begin{array}{l}\text { Had days off work (adults 18-64 } \\
\text { working in year 2) }\end{array}$ & $\begin{array}{c}195(487) \\
(101 \text { not in } \\
\text { work) }\end{array}$ & $\begin{array}{c}223(500) \\
(77 \text { not in } \\
\text { work) }\end{array}$ & $149(588)$ & $19(/ 577)$ & $\begin{array}{l}0.65(0.50 \text { to } 0.83) \\
\quad P=0.0007\end{array}$ & 0.62 (0.46 to 0.83$) \mathrm{P}=0.0017^{\star}$ \\
\hline $\begin{array}{l}\text { Number of days working adults had off } \\
\text { work§ }\end{array}$ & Count data & & & & & $\begin{array}{l}0.63(0.41 \text { to } 0.96) P=0.033 \pi, \\
0.62(0.47 \text { to } 0.82) P=0.001 \rrbracket\end{array}$ \\
\hline $\begin{array}{l}\text { Number of days working adults had off } \\
\text { work§ }\end{array}$ & Count data & & & & & $\begin{array}{l}0.62(0.40 \text { to } 0.97) \mathrm{P}=0.034,^{\star \star} \\
0.609(0.45 \text { to } 0.82) \mathrm{P}=0.001)^{\star \star}\end{array}$ \\
\hline \multicolumn{7}{|l|}{ Days off school } \\
\hline $\begin{array}{l}\text { Had days off school (6-17 year olds in } \\
\text { school, year } 1)\end{array}$ & $175(246)$ & $183(257)$ & $149(246)$ & $189(257)$ & $\begin{array}{l}0.553(0.379 \text { to } \\
0.806) \mathrm{P}=0.001\end{array}$ & $0.49(0.31$ to 0.80$) \mathrm{P}=0.004 \ddagger$ \\
\hline $\begin{array}{l}\text { Number of days 6-17 year olds had off } \\
\text { school§ }\end{array}$ & Count data & & & & & $\begin{array}{l}0.47(0.27 \text { to } 0.81) \mathrm{P}=0.007 \dagger \dagger \\
0.81 \text { (1.01 to } 1.51) \mathrm{P}=0.044 \dagger \dagger\end{array}$ \\
\hline \multicolumn{7}{|c|}{$\begin{array}{l}\text { Twelve babies were born in the year between the first and second winter; } 7 \text { in the intervention group and } 5 \text { in th } \\
\text { received National Health information. } \\
\text { All adjusted odds ratios adjusted for age group, sex, and ethnic origin. } \\
\text { *Also adjusted for year } 1 \text { score or status, household, and region. } \\
\dagger \text { Also adjusted for household and region. } \\
\ddagger \text { Also adjusted for household. } \\
\text { §The first set of results used a zero inflated negative binomial model; the second set is the incident rate ratio. } \\
\text { ๆAlso adjusted for region and non-working adult in house. } \\
\star \star A l s o \text { adjusted for region and number of working adults in house. } \\
\dagger † \text { Also adjusted for region and number of } 6-17 \text { year olds in house. }\end{array}$} \\
\hline
\end{tabular}


Table $7 \mid$ Self reported SF-36 results in a trial of insulating houses. Results are mean score in adults who had data for both years, unless stated otherwise

\begin{tabular}{|c|c|c|c|c|c|c|}
\hline \multirow[b]{2}{*}{ Scale } & \multicolumn{2}{|c|}{ Before intervention } & \multicolumn{2}{|c|}{ After intervention } & \multicolumn{2}{|c|}{ Difference $(95 \% \mathrm{Cl})$} \\
\hline & $\begin{array}{l}\text { Interven- } \\
\text { tion group }\end{array}$ & $\begin{array}{l}\text { Control } \\
\text { group }\end{array}$ & $\begin{array}{l}\text { Interven- } \\
\text { tion group }\end{array}$ & $\begin{array}{c}\text { Control } \\
\text { group }\end{array}$ & Unadjusted & Adjusted \\
\hline $\begin{array}{l}\text { Social } \\
\text { functioning }\end{array}$ & 69.2 & 69.3 & 78.4 & 72.3 & $\begin{array}{c}6.1 \text { ( } 3.9 \text { to } 8.4) \\
P<0.0001\end{array}$ & $\begin{array}{c}6.2(3.8 \text { to } 8.6) \\
\text { P } 0.0001^{*}\end{array}$ \\
\hline Role emotional & 63.1 & 62.4 & 77.5 & 66.7 & $\begin{array}{c}10.8(7.2 \text { to } 14.5) \\
\text { P }<0.0001\end{array}$ & $\begin{array}{c}10.9 \text { (7.1 to } 14.6 \\
\text { P }<0.0001^{*}\end{array}$ \\
\hline Role physical & 52.5 & 52.2 & 70.0 & 58.8 & $\begin{array}{l}11.2(7.4 \text { to } 15) \\
\text { P } 0.0001\end{array}$ & $\begin{array}{c}11.8 \text { (8.0 to } 15.5 \\
P<0.0001^{*}\end{array}$ \\
\hline
\end{tabular}

${ }^{\star}$ Adjusted for score at baseline, age group, sex, ethnic origin, household, and region.

groups was smaller $(0.90,0.59$ to $1.37 ; \mathrm{P}=0.61)$. The difference between the two groups in terms of the numbers of days in hospital for respiratory conditions was also non-significant (table 9).

\section{DISCUSSION}

Our study used a community approach to investigate an important environmental determinant of health. All outcome measures improved with insulation, and except for the use of healthcare facilities, results were statistically significant. The effect size was greater for the self reported data, although independent housing inspectors judged the houses to be in worse condition than did the occupants.

\section{Limitations and strengths of the study}

Our study adopted an experimental intervention approach but was of necessity only single blinded. The independent building inspectors and the community interviewers were not told which households were in the intervention group. it was not practical to install insulation without the knowledge of the householders or landlords, so during follow-up some householders may have mentioned the intervention to the interviewers. However, this possible bias was minimised by the collection of external data gathered from independent sources such as power companies, general practitioners, and hospitals.

Historically undemanding housing regulatory standards, such as no requirement for insulation in the building code until 1977, helps explain why about a third of houses are not insulated in New Zealand. ${ }^{31}$ By targeting uninsulated households where at least one member had current respiratory symptoms we identified a group of people whose homes were more likely to be older, colder, and damper than in the general population, and where increased warmth and decreased humidity and damp might be expected to have a greater effect. Also, because of the areas targeted and the local organisations involved, the population contained a disproportionately high proportion of Maori and Pacific people, who have higher morbidity and premature mortality than Europeans. ${ }^{2032}$

Some economists have argued that low household income rather than substandard housing is the fundamental problem underlying health inequality. ${ }^{33}$ Such confounding makes a randomised controlled trial like ours important for determining cause and effect. Income and housing are obviously inter-related, but it is easier to upgrade low income housing than to redistribute income.

\section{Benefits of insulation}

Fitting older homes with insulation led to a statistically significant increase in the indoor temperature and a decrease in relative humidity. The frequency of exposure to temperatures below $10^{\circ} \mathrm{C}$ was reduced by $30 \%$ and mean relative humidity fell by $3.8 \%$. The occupants' reduced exposure to low temperature and high humidity may be the main reason that they reported a significantly higher level of comfort. Alternatively, insulation may have reduced heat transfer between the occupants and the outside or the occupants may have had an increased sense of control over their fuel bills.

People in insulated houses also reported that their houses felt significantly less damp and mouldy, but our study does not identify the key environmental factors involved. The association between living or working in a damp building and health effects such as cough, wheeze, allergies, and asthma is well established. However, it is not possible to define a damp building in health relevant terms, or to specify which agents in damp buildings have detrimental effects on health. ${ }^{8}$

Table 8 | Use of health care in a trial of insulating houses. Values are number of people (total number of people with available data) unless stated otherwise

\begin{tabular}{|c|c|c|c|c|c|c|}
\hline \multirow[b]{2}{*}{ Outcome measure } & \multicolumn{2}{|c|}{ Before intervention } & \multicolumn{2}{|c|}{ After intervention } & \multicolumn{2}{|c|}{ Odds ratio $(95 \% \mathrm{Cl})$} \\
\hline & $\begin{array}{l}\text { Intervention } \\
\text { group }\end{array}$ & $\begin{array}{l}\text { Control } \\
\text { group }\end{array}$ & $\begin{array}{l}\text { Intervention } \\
\text { group }\end{array}$ & $\begin{array}{l}\text { Control } \\
\text { group }\end{array}$ & Unadjusted & Adjusted \\
\hline \multicolumn{7}{|l|}{ Primary care } \\
\hline Self reported visit to general practitioner & $813(1448)$ & 769 (1396) & $664(1448)$ & $715(1396)$ & $0.81(0.70$ to 0.94$) \mathrm{P}=0.0043$ & 0.73 (0.62 to 0.87$) \mathrm{P}=0.0002 \dagger$ \\
\hline General practitioner reported visit & $814(1390)$ & $765(1346)$ & 769 (1390) & $743(1346)$ & $1.01(0.86$ to 1.17$) \mathrm{P}=0.9484$ & 0.95 (0.81 to 1.13) $\mathrm{P}=0.58 \dagger$ \\
\hline \multicolumn{7}{|l|}{ Secondary care* } \\
\hline $\begin{array}{l}\text { Admitted to hospital; main code a respiratory } \\
\text { condition }\end{array}$ & 7 (1379) & $10(1340)$ & $8(1386)$ & $14(1345)$ & $0.552(0.23$ to 1.32$) \mathrm{P}=0.18$ & $\begin{array}{c}0.53(0.22 \text { to } 1.29) P=0.16 x^{2} / \\
d f=0.89 \ddagger\end{array}$ \\
\hline Admitted to hospital; main code a control condition & $48(1379)$ & $56(1340)$ & $43(1386)$ & $48(1345)$ & $0.865(0.569$ to $1.312 ; P=0.50)$ & $0.90(0.59$ to 1.37$) \mathrm{P}=0.61 \S$ \\
\hline
\end{tabular}

Outcomes were measured on people with attendance records for both years in primary care and by using a unique identifier in the second year in secondary care.

All adjusted odds ratios were adjusted for age, sex, and ethnic origin.

*Twelve babies were born in the year between the first and second winter; 7 in the intervention group and 5 in the control group.

†Also adjusted for baseline value and region.

$\ddagger$ Also adjusted for region. 
Table 9 | Frequency table for hospital admissions in a trial of insulating houses. Values are number of times admitted during winter of the second year (number of people admitted that many times) unless stated otherwise

\begin{tabular}{|c|c|c|c|c|c|c|}
\hline \multirow[b]{2}{*}{ Outcome measure } & \multicolumn{2}{|c|}{ Before intervention } & \multicolumn{2}{|c|}{ After intervention } & \multicolumn{2}{|c|}{ Odds ratio $(95 \% \mathrm{Cl})$} \\
\hline & $\begin{array}{l}\text { Intervention } \\
\text { group }\end{array}$ & Control group & Intervention group & Control group & Unadjusted & Adjusted \\
\hline $\begin{array}{l}\text { Number of people admitted } \\
\text { with a respiratory condition } \\
\text { as main code }\end{array}$ & $0(1372) ; 1(7)$ & $0(1330) ; 1(9) ; 2$ (1) & 0 (1378); 1 (7); 2 (1) & $\begin{array}{c}0 \text { (1331); } 1 \text { (13); } 2 \\
\text { (1) }\end{array}$ & $\begin{array}{l}0.58 \text { (0.04 to } \\
8.93) \mathrm{P}=0.697\end{array}$ & $\begin{array}{c}0.21 \text { (0.01 to } \\
\text { 3.13); } P=0.255^{\star}\end{array}$ \\
\hline $\begin{array}{l}\text { Number of people admitted } \\
\text { with a control condition as } \\
\text { main code }\end{array}$ & $\begin{array}{l}0(1331) ; 1 \\
(44) ; 2(4)\end{array}$ & $\begin{array}{c}0 \text { (1284); } 1(51) ; 2 \\
(4) ; 3(1)\end{array}$ & 0 (1343); 1 (40); 2 (3) & $\begin{array}{c}0 \text { (1297); } 1(43) ; 2 \\
\text { (5) }\end{array}$ & $\begin{array}{l}1.48(0.36 \text { to } \\
6.06) P=0.589\end{array}$ & $\begin{array}{c}0.47 \text { (0.19 to } \\
1.18) ; \mathrm{P}=0.107^{\star}\end{array}$ \\
\hline $\begin{array}{l}\text { Outcomes were measured by } \\
\text { All adjusted odds ratios were } \\
\text { Twelve babies were born in } t \\
\text { * Results derived by using the }\end{array}$ & $\begin{array}{l}\text { sing a unique } \\
\text { djusted for a } \\
\text { year betwee }\end{array}$ & $\begin{array}{l}\text { entifier. } \\
\text { sex, and ethnic ori } \\
\text { he first and second }\end{array}$ & $\begin{array}{l}\text { inter; } 7 \text { in the interve } \\
\text { vint }\end{array}$ & ion group and 5 in $t$ & control group. & \\
\hline
\end{tabular}

Householders spent significantly less on heating their houses after the intervention, and these savings may have increased their effective disposable income. The finding that householders took advantage of the efficiency gains to lower energy consumption is consistent with the relatively small change in mean temperature and other empirical studies in this area. ${ }^{34-36}$ It also suggests that the improvement seen in health was not due to average temperature and humidity changes, which were relatively small, but to larger changes in exposure to very low temperatures and high humidity.

Our study showed that a relatively modest investment in insulation per house (around $£ 700$ excluding taxes, or the cost of one inpatient hospital admission) led to significant improvements in the population's self reported health and a lower risk of children having time off school or adults having sick days off work. Participants in the intervention group reported significant improvements in their general health, respiratory symptoms, and sense of comfort and wellbeing. We saw no reduction in visits to general practitioners according to official reports; however, the absence of a unique patient identifier in primary care means that patients' recall of visiting several general practitioners, which is common in New Zealand, may be more accurate than the records from their main practitioner. In secondary care, where a unique patient identifier exists, we saw a trend towards fewer admissions to hospital and fewer days in hospital for respiratory conditions.

Evidence from a major British cohort study has shown that the effects of poor housing conditions are cumulative over the life course. ${ }^{37}$ Thus, housing interventions can have significant health multiplier effects. A conservative cost-benefit analysis of this intervention trial indicated that the tangible health and energy benefits outweighed the costs by a factor approaching 2 , when calculated in present value terms at a $5 \%$ real discount rate over 30 years, and that the energy savings component covered around half the cost of the insulation. ${ }^{38}$ Such robust health, wellbeing, and economic outcome measures provide the kind of information used by the National Institute for Health and Clinical Evidence in the United Kingdom to develop their guidelines for effective public health interventions.

\section{CONCLUSION}

Our study has shown that it is possible to balance the practicalities of working in partnership with communities with the rigour of a randomised controlled study. Improving the thermal properties of older houses led to warmer houses and had demonstrable health benefits. Interventions of this kind, which focus on low income communities and poorer quality housing, have the potential to reduce health inequalities. ${ }^{39}$ Fitting insulation is a cost effective intervention for improving health and wellbeing and has a high degree of acceptance by the community, policy makers, and politicians.

We would like to thank Olivia James at Otara Health Inc; Jo Hunt at Opotiki Trade Training; Pounamu Skelton and the New Plymouth Office of Te Puni Kokiri; Johnina Stymes and Alberta Hunga at Te Iwi o Rakaipaaka; Elyria Fau at Te Wahine o Kahungungu; Gail Chalmers and Porirua Housing Action Group; Linda Wall, June Robinson, and the Rata Branch of the Maori Women's Welfare League; Ann Currie at Crown Public Health; the interviewers and retrofit teams; and all the householders who took part in our study. We are grateful to our community coordinators the late Ruth Nepia, Pounamu Skelton, and Jo-Ani Robinson. We also thank the general practitioners, the National Health Information Service, the energy companies who supplied us with utilisation data, and June Atkinson, who carried out the randomisation.

Funding: The Health Research Council of New Zealand, the Energy Efficiency and Conservation Authority, the Ministry of Health, Solid Energy, Orion, Christchurch City Council, Environment Canterbury, Hutt Mana Community Trust, MARIA, Eastern Bay of Plenty Energy Trust, Wellington City Council, and Housing New Zealand Corporation.

Competing interests: None declared.

Ethical approval: This multicentre study was approved by the central region ethics committee.

Contributors: $\mathrm{PH}-\mathrm{C}$ helped design, perform, analyse, and write up the study. AM helped design, perform, and write up the study. JC helped design, analyse, and write up the study. HV helped carry out, analyse, and write up the study; MC, TC, DD, RC, NW helped design, analyse, and write up the study. CC, KSS, AW,

\section{WHAT IS KNOWN ON THIS TOPIC}

Damp, cold, and mouldy houses are associated with poor health

\section{WHAT THIS STUDY ADDS}

Insulating existing houses makes the indoor environment significantly warmer and drier, while lowering energy use

Fitting insulation significantly improves occupants' self rated health, self reported wheezing, days off school or work, and visits to general practitioners, and results in fewer hospital admissions for respiratory conditions 
and MB helped design and write up the study. GD provided biostatistical advice. $\mathrm{PH}-\mathrm{C}$ is guarantor

1 Rose G. The strategy of preventive medicine. Oxford: Oxford University Press, 1992.

2 Krieger J, Higgins D. Housing and health: time again for public health action. Am I Public Health 2002;92:758-68.

3 Oakley A. Experimentation and social interventions: a forgotten but important history. BMJ 1998;317:1239-42.

4 Thomson H, Hoskins R, Petticrew M, Ogilvie D, Craig N, Quinn T, et al. Evaluating the health effects of social interventions. $B M$ J 2004;328:282-5.

5 Thomson H, Petticrew M, Morrison D. Health effects of housing improvement: systematic review of intervention studies. $B M J$ 2001;323:187-90

6 Thomson H, Atkinson R, Petticrew M, Kearns A. Do urban regeneration programmes improve public health and reduce health inequalities? A synthesis of the evidence from UK policy and practice (1980-2004). J Epidemiol Community Health 2006;60:108-15.

7 Howden-Chapman P. Housing standards: a glossary of housing and health. J Epidemiol Community Health 2004;58:162-8.

8 Sundell J. On the history of indoor air quality and health. Indoor Air 2004; 14:51-8

9 Wanless D. Securing good health for the whole population. London: HM Treasury and Department of Health, Stationery Office, 2004.

10 The Eurowinter Group. Cold exposure and winter mortality form ischaemic heart disease, cerebrovascular disease, respiratory disease, and all causes in warm and cold regions of Europe. Lancet 1997;349:1341-6.

11 Wilkinson P, Landon M, Armstrong B, Stevenson S, Pattenden S, McKee M, et al. Cold comfort: the social and environmental determinants of excess winter deaths in England, 1986-1996. London: Policy Press, 2001.

12 Boardman B. Fuel poverty: from cold homes to affordable warmth London: Belhaven Press, 1991.

13 Heyman B, Harrington BE, Merleau-Ponty N, Stockton H, Ritchie N, Allan TF. Keeping warm and staying well. Does home energy efficiency mediate the relationship between socio-economic status and the risk of poorer health? Housing Studies 2005;20:649-64.

14 Healy JD. Housing, fuel poverty and health: a pan-European analysis. Aldershot: Ashgate, 2004.

15 Curwen M. Excess winter mortality: a British phenomenon? Health Trends 1990/91;22:169-75.

16 Tobin R, Baranowski E, Gilman A, Kuiper-Goodman, T, Miller, JD, Giddings, M. The significance of fungi in indoor air. Can J Public Health 1987;78:S1-14.

17 Institute of Medicine of the National Academies. Damp indoor spaces and health. Washington, DC: National Academies Press, 2004.

18 Bonnefoy XR, Braubach M, Moissonnier B, Monolbaev K, Robbel N. Housing and health in Europe: preliminary results of a pan-European study. Am J Public Health 2003;93:1559-63.

19 Acheson D. Independent inquiry into inequalities in health report London: Stationery Office, 1998.

20 Howden-Chapman P, Tobias M, eds. Social inequalities in health: New Zealand 1999. Wellington: Ministry of Health, 2000.

21 Department of Health. Our healthier nation: a contract for health. $\mathrm{Cm}$ 3852. London: Stationery Office, 1998.
22 Howden-Chapman P, Crane J, Matheson A, Viggers $\mathrm{H}$, Cunningham M, Blakely T, et al. Retrofitting houses with insulation to reduce health inequalities: aims and methods of a clustered, randomised trial in community settings. Social Sci Med 2005;61:2600-10.

23 Campbell MK, Elbourne DR, Altman D, for the CONSORT Group. CONSORT statement: extension to cluster randomised trials. $B M$ 2004;328:702-8.

24 National Institute of Water and Atmospheric Research. The climate of New Zealand. Wellington: NIWAR, 2004.

25 Isaacs N, Amitrano L, Camilleri M, Pollard A, Stoecklein A. Energy use in New Zealand households. Report on the year 7 analysis for the household energy end-use project (HEEP). Porirua City, New Zealand: Building Research Association of New Zealand, 2003. www.branz. co.nz/branzltd/pdfs/HEEP7Exe.pdf? PHPSESSID=b7eff78229dce18fc6f13fa276606986.

26 Matheson A, Howden-Chapman P, Dew K. Engaging communities to reduce inequalities in health: why partnership? Social Policy J New Zealand 2005;26:1-16.

27 Ware JE, Snow KK, Kosinski M, Gandek B. SF36 health survey. Manual and interpretation guide. Boston, MA: Health Institute, 1993.

28 Wickens K, Mason K, Fitzharris P, Siebers R, Hearfield M, Cunningham $\mathrm{M}$, et al. The importance of housing characteristics in determining Der $\mathrm{p} 1$ levels in carpets in New Zealand homes. Clin Exp Allergy 2001;31:827-35.

29 Vickers A, Altman DG. Analysing controlled trials with baseline and follow-up measurements. BMJ 2001;323:1123-4.

30 Cunningham M, Viggers $\mathrm{H}$, Camilleri M, Matheson A, Howden-Chapman P. Changes of exposure to low temperatures and high humidities on retrofitting houses with insulation. In: Second WHO international housing and health symposium. Bonn, Germany: WHO European Centre for Environment and Health, 2004:423-33.

31 Clark S, Page I, Bennett A, Bishop S. New Zealand house condition survey. Porirua City, New Zealand: Building Research Association of New Zealand, 2000.

32 Blakely T, Tobias M, Tobson B, Ajwani S, Bonne M, Woodward A Widening ethnic mortality disparities in New Zealand 1981-99. Social Sci Med 2005;61:2233-51.

33 Le Grand J, Propper C, Robinson R. The economics of social problems. 3rd ed. Hampshire: Palgrave, 1984.

34 Hirst E, White D, Goeltz R. Indoor temperature changes in retrofit homes. Energy 1985;10:861-70.

35 Melkas TA, Koskinen SV. Health targets in Finnish national policy. Eur J Public Health 2000;10(suppl 4):43-4.

36 Greening LA, Greene DL, Digfiglio C. Energy efficiency and consumption - the rebound effect-a survey. Energy Policy 2000;28:389-401.

37 Marsh A, Gordon D, Pantazis C, Heslop P. Home sweet home? The impact of poor housing on health. London: Policy Press, 1999.

38 Chapman R, Howden-Chapman P, O'Dea D, Viggers H, Kennedy M. Retrofitting houses with insulation: a cost-benefit analysis of a randomised community trial. Wellington, New Zealand; Housing and Health Research Programme, 2004. www.maarama.co.nz/ Insulation_Benefits_feb07.doc.

39 Graham H, ed. Understanding health inequalities. London: Open University Press, 2001.

Accepted: 14 December 2006 